\title{
Does Social Responsibility Increase Corporate Value of China's Coal Enterprises? The Mediating Effect of Capital Enrichment Based on the Generalized Moment Estimation
}

\author{
Fengju XU ${ }^{1}$, Lina MA ${ }^{2^{*}}$, Lusianna LIUNATA ${ }^{3}$, Iqbal NAJAF ${ }^{4}$ and \\ Dalia STREIMIKIENE ${ }^{5}$
}

Authors' affiliations and addresses:

${ }^{1}$ School of Management, Wuhan University of Technology, Hubei, Wuhan, China

e-mail: xufju@whut.edu.cn

${ }^{2}$ School of Management, Wuhan University of Technology, Hubei, Wuhan, China e-mail: Malina132@163.com

${ }^{3}$ School of Management, Wuhan University of Technology, Hubei, Wuhan, China e-mail: lusianna.liunata@yahoo.com

${ }^{4}$ School of Finance, Anhui University of Finance and Economics, Bengbu, Anhui, China e-mail: najaf_iqbal@live.com

${ }^{5}$ Lithuania Sports University, Sporto g. 6, Kaunas 44221, Lithuania

e-mail: dalia.streimikiene@1su.lt

*Correspondence:

Lina Ma, School of Management, Wuhan University of Technology, Hubei, Wuhan, China tel.: +8613526224667

e-mail: Malina132@163.com

Funding information:

Funding Agency: China's National Social

Science Fund

Grant Number: 15BJY065

How to cite this article:

Xu, F., Ma, L., Liunata, L., Najaf, I. and Streimikiene, D. (2020). Does Social

Responsibility Increase Corporate Value of China's Coal Enterprises? The Mediating Effect of Capital Enrichment Based on the Generalized Moment Estimation. Acta Montanistica Slovaca, Volume 25 (3), 274-288

DOI:

https://doi.org/10.46544/AMS.v25i3.2

\begin{abstract}
In the context of the new normal in China's economy, the development of coal enterprises continues to be sluggish, and their social responsibility issues have received increased attention from all walks of life. The stakeholder model of social responsibility was constructed based on the stakeholder theory to reveal the influence of social responsibility on the corporate value in the Chinese coal sector and their transmission mechanism. The panel data of coal enterprises in Shenzhen and Shanghai Stock Exchanges from 2011 to 2019 was used to employ the system GMM (Generalized Moment Estimation) and the mediating effect model for empirical research. The results show that social responsibility has a positive influence over corporate value, and the impact of social responsibility on corporate value is heterogeneous for stakeholders in different dimensions. Social responsibility towards employees, shareholders, creditors, resources, and the environment has the greatest contribution to corporate value. Additionally, capital enrichment plays a mediating role in this effect, which enhances the positive impact of social responsibility on corporate value. Such findings reveal the transmission mechanism of social responsibility on corporate value and provide policy suggestions for coal enterprises to promote their sustainable development, which is beneficial for the national energy security and strategy.
\end{abstract}

\section{Keywords}

Coal enterprises; Social responsibility; Corporate value; Capital enrichment; Strategic energy. 


\section{Introduction}

The Chinese coal industry is closely related to its energy security, ecological environment, people's livelihood, and commercial activities and is an important strategic resource for the country. With China's rapid development, the demand for coal continues to increase, and its annual production has reached four billion tons recently. However, the average coal extraction rate is only about $68 \%$, which still has a large gap compared with the developed countries. Due to China's coal enterprises' outdated production and technological level, they have relied on extensive and extended development paths for a long, resulting in high energy consumption and stumpy resource utilization (Kasperowicz, 2014). The growth rate of technology research and development is much lower than the rate of environmental degradation, and firms are facing an urgent need for transformation and upgrading.

The emphasis on emission reduction has been placed in contemporary studies (Xu et al., 2020). As the coal resources are non-renewable, the reserves are very limited as compared to the current demand. In the context of constructing a spatial pattern of resource conservation and environmental protection, a typical coal enterprise has a natural mission to accomplish, i.e., social responsibility. In addition to corresponding responsibilities towards shareholders, employees, consumers, creditors, government departments and communities, etc., they should also perform duties to protect the ecological environment, improve resource utilization, and produce safely. However, as of August 2020, only 28 coal enterprises have issued social responsibility reports. While expanding production and scale, coal enterprises always ignore their social responsibility, which is mainly manifested in poor production safety awareness, low resource utilization, insufficient safety investment, extensive environmental pollution, and poor labor-management relations (Guo, Wang and Chen, 2011). In China, the coal industry's frequent occurrence of safety accidents has seriously endangered the social environment. Some enterprises have declined in profits and even experienced operating losses, which is not conducive to this industry's healthy and sustainable development.

The social responsibility of coal enterprises is an inevitable requirement of social development and guarantees maintaining national energy security and promoting economic quality and efficiency. It also plays an important role in the world's energy supplies (Lorenzo et al., 2018). For coal enterprises, fulfilling social responsibility is conducive to promoting safe production, improving the comprehensive utilization of coal resources, and increasing enterprises' competitiveness. It may create greater economic benefits or reputation (Kum, Vinh and Yiik, 2016; Rothenhoefer, 2019), which are reflected in the form of positive changes in corporate value. Social responsibility reports showing good performance on this metric can effectively reduce capital cost and play a greater role in effective disclosure (Dhaliwal et al., 2011; Dustin and Eric, 2020). From China's coal enterprises' development practice, most of them are state-owned enterprises with a monopoly in access to resources and bear profit advantages. Driven by the national policy orientation and the profit-seeking nature of capital, a large amount of capital accumulates to form the phenomenon of capital enrichment, which in turn provides scarce production factors for the innovation and development of the coal industry. Apart from an increase in the total amount of capital, it may also cause a redistribution of innovation resources such as information, knowledge, and talent among different enterprises (Xu, Ma and Najaf, 2020), thereby positively affecting the value creation in this sector.

In 2020, the Guidance and Recommendations on Accelerating the Intelligent Development of Coal Industry was jointly issued by the National Development and Reform Commission, the National Energy Administration, the Ministry of Emergency Response and Finance, the National Coal Mine Safety Supervision Bureau, and the Ministry of Science and Technology. It pointed out that the coal industry's supply-side reforms should be continuously promoted, and the intelligent coal mine can be taken as a core technology support for high-quality development. Compared with the traditional mechanized production, it increases the capital investment by $30 \%$ and opens up the space for new infrastructure construction in the coal industry. However, the coal innovation output quality and technological progress in China are still at a lower level, and the key technologies are heavily dependent on external sources, representing an obvious situation similar to the "Solo Paradox" phenomenon.

The current academic research on the relationship between social responsibility, corporate value, and capital enrichment still has some limitations. First, the existing literature on social responsibility is scarce in the coal industry, and it mainly focuses on normative research, such as the construction of the evaluation system and information disclosure (Herbas, Frank and Arandia, 2018; Rita and Diego, 2020; Isabel and García, 2020). At the same time, there are many inconsistencies in the classification of social responsibility based on the perspective of stakeholders, including the classification by capital forms, capital sources, and symbiotic relationships. Second, the impact of social responsibility on corporate value is inconclusive. Some studies find that coal enterprises' social responsibility performance positively impacts corporate value (Ruf et al., 2010; Li, Li and Minor, 2015; Mehralian et al., 2016; Zerbini, 2017). However, there is heterogeneity in different equity, credit markets (Sadok, Ghoul and Yongtae, 2017), equity structure (Rjiba, Jahmane and Abid, 2020), and institutional environment (Woo, Kunsu and Sang, 2018). Others suggest a negative (Crisóstomo, Freire and Vasconcellos, 2011) or even an inverted U-shaped relationship (Shen and Liu, 2012) between social responsibility and corporate value. The 
underlying reason may be the fact that the social responsibility for stakeholders in different dimensions has a varying impact on corporate value (Lyon and Maxwell, 2008). Third, the role of capital enrichment in the relationship between social responsibility and corporate value is ignored. This study studies the relationship between coal enterprises' social responsibility, corporate value, and capital enrichment and mainly focuses on answering the following questions.

RQ1: Does social responsibility have an impact on corporate value in China's coal sector firms? Is that impact positive or negative?

RQ2: Is the impact of social responsibility on corporate value heterogeneous for different stakeholders?

RQ3: Does the capital enrichment phenomenon affect the relationship between social responsibility and corporate value? What is the influencing mechanism?

This study selects the listed coal companies in Shenzhen and Shanghai Stock Exchanges from 2011 to 2019 as research samples and constructs a stakeholder model of coal corporate social responsibility based on stakeholder theory. The entropy weight method and GMM (Generalized Moment Estimation) are adopted for empirical research to explore the relationship between social responsibility, corporate value, and capital enrichment. The contribution of this study is as follows. First, the GMM model is used to investigate the relationship between social responsibility and corporate value of coal enterprises, which alleviates the endogeneity problem caused by the reverse causality, and provides a complete logical framework and empirical evidence. Second, coal enterprises' stakeholders are segregated into human capital, monetary capital, social capital, and environmental capital. It attempts to reveal the heterogeneous impact of social responsibility for stakeholders of different dimensions on coal enterprises' corporate value. Meanwhile, it considers the mediating effect of capital enrichment on the relationship between the above two, which provides theoretical support and an internal logical framework. On this basis, the study puts forward implications to improve the coal enterprises' corporate value and sustainable development.

\section{Literature Review and Research Hypothesis}

\section{Social Responsibility and Corporate Value}

Scholars have remained engaged in extensive research and discussion on corporate social responsibility (CSR) since Sheldon formally proposed it in 1923. However, there is no unified conclusion and consensus on the concept of corporate social responsibility. Carroll (1979) defined it as the economic, legal, ethical, and charitable responsibilities that an enterprise undertakes in a certain period and proposes a "pyramid" model of social responsibility on these grounds. Subsequently, the concept of corporate social responsibility in different dimensions began to emerge. It has gone through the initial stage, preliminary development stage, and rapid development stages since the 1990s. Some scholars analyze it from the perspective of the law, management, economics, and sociology. Liu (1999) analyzed from the perspective of law and suggested that corporate social responsibility is the responsibility to protect the interests of other subjects while pursuing the maximization of shareholders' profits. Baron (2001) defined it as a non-profit social or environmentally friendly behavior based on economic theory. Seen from the perspective of sociology, Lyon and Maxwell (2008) pointed out that it has the characteristics of altruism and moral motivation. Although the definition of corporate social responsibility is disputed, it can be said that it is the responsibility that enterprises undertake towards different stakeholders and has multiple attributes.

The relationship between social responsibility and the corporate value was first discussed in 1970 and gradually formed two viewpoints. First, the greater the corporate social responsibility, the higher the corporate value (Kim et al., 2011; Kum, Vinh and Yiik, 2016; Mehralian et al., 2016). The active fulfillment of social responsibilities can be used as an important means of external signal transmission (Connelly et al., 2011; Zerbini, 2017 ) to reduce the information asymmetry between internal managers and stakeholders (Luo et al., 2015; Wang and Li, 2016). It also improves enterprises' reputations (Godfrey, Merrill and Hansen, 2009; Borghesi, Houston and Naranjo, 2012) and consolidates the cooperative relationship with stakeholders (Mehralian et al., 2006), thereby increasing the corporate value. Ruf et al. (2001) took the KLD index method to measure corporate social responsibility and suggest that it can both improve the current and future financial performance. Enterprises prefer to undertake more social responsibility if they expect to obtain higher economic benefits (Waddock and Graves, 2015; Orlando, 2020), forming a positive synergistic effect. However, some scholars with the second type of viewpoint believed that social responsibility is a tool for companies to cover up unethical behavior (Quan, $\mathrm{Wu}$ and Yin, 2015), which is negatively correlated with corporate value (Sekhon and Kathuria, 2019). Crisóstomo, Freire and Vasconcellos (2011) divided the samples into the experimental and the control group to conduct a comparative analysis and found that the stock market value of companies performing social responsibility is lower than those who do not.

Since China's coal enterprises are mainly state-owned enterprises, which are important for the government's strategic objective of long-term social development (Ma et al., 2020), this study argues that it sends a positive message to the investors if they fulfill social responsibilities. This, in return, attracts more 
capital and avoids the problem of insufficient caused by the rupture of the capital chain (Dhaliwal et al., 2011; Cheng, Goh and Kim, 2018). Coal enterprises will be encouraged to invest capital in innovation research and development to improve their technical level. Meanwhile, the information disclosure related to social responsibility can positively affect managers' operation decisions to improve the investment and resource allocation efficiency, which is finally reflected in an increased corporate value (Lin and Fu, 2017). So, the following hypothesis is proposed.

H1: The social responsibility of coal enterprises has a positive effect on their corporate value.

Since the conflicts between different interests are inevitable (Kondić and Balić, 2019), there is no unified conclusion on the impact of social responsibility on corporate value. The reason may be that stakeholders in different categories such as shareholders, employees, and creditors have different interest targets, resulting in the differences in corporate value generated by coal enterprises when performing corresponding social responsibility tasks. Some authors analyze this situation from three dimensions of employees, customers, and suppliers. The result shows that employees' social responsibility contributes the most to the growth and long-term development of enterprises, followed by customers and suppliers. Liu and Song (2011) analyzed the relationship between social responsibility for stakeholders in different dimensions and corporate value from the perspective of the company's internal structure. The result showed that corporate value is positively correlated with the customer and environment dimensions but negatively corrected with the social charity dimension. Long and Song (2013) analyzed the mechanism of social responsibility and value creation based on the perspective of reputation capital. They pointed out that the social responsibility for employees, consumers, investors, and communities is conducive to credit capital formation, thus promoting positive transactions and enhancing value creation. However, Fernández and Sarria (2018) suggested that employees' social responsibility has a negative impact on corporate value. So, the following hypothesis is proposed after considering the arguments mentioned above.

$\mathrm{H} 2$ : The impact of social responsibility on corporate value is heterogeneous for different stakeholders.

\section{Social Responsibility, Corporate Value, and Capital Enrichment}

In recent years, coal enterprises have actively deployed special programs to improve quality and efficiency. With the support of government policies, the coal industry's capital enrichment level has fluctuated but increased, which has an impact on corporate value also. First, given the profit-driven nature of capital, it flows rapidly to industries with a higher return on investment (Wurgler, 2000), resulting in a reallocation of scarce capital. Capital enrichment is beneficial to an industry's investors as it can ease the financing constraints, which brings improvement through investment in R\&D activities. It also attracts more high-quality investors into the coal industry, improves the capital market's liquidity, and results in capital allocation efficiency (Vollrath, 2009). This process can lead to a higher-value appreciation. Yu, Huang and Cao (2015) verified that the influence of social responsibility on corporate value is to maximize the long-term economic interests by increasing capital accumulation. Second, capital enrichment is the result of concentrated capital flows and plays an important role in guiding capital investment and volume, market information discovery, and promoting the transfer of economic resources among industries and/or enterprises. This phenomenon improves the information transmission related to coal enterprises and reduces market participants' transaction costs by reducing moral hazard and adverse selection, which is ultimately reflected in the value of coal enterprises.

From the perspective of economics, it can be found that the capital flow reflects the cooperation tendency among transaction subjects. The long and high-yield investment projects promote information sharing between the coal companies and investors. It reduces agency costs and creates a better investor protection environment (Walaa, 2018; Lu et al., 2020), which plays an important role in improving coal enterprises' investment efficiency to achieve excess earnings and enhance their innovation capability (Lu et al., 2019). Therefore, the social responsibility of coal enterprises can affect corporate value indirectly through capital enrichment. The impact path is as shown in Figure 1, and the following hypothesis is proposed.

H3: Capital enrichment plays a mediating role in the relationship between social responsibility and corporate value in the Chinese coal sector firms. 


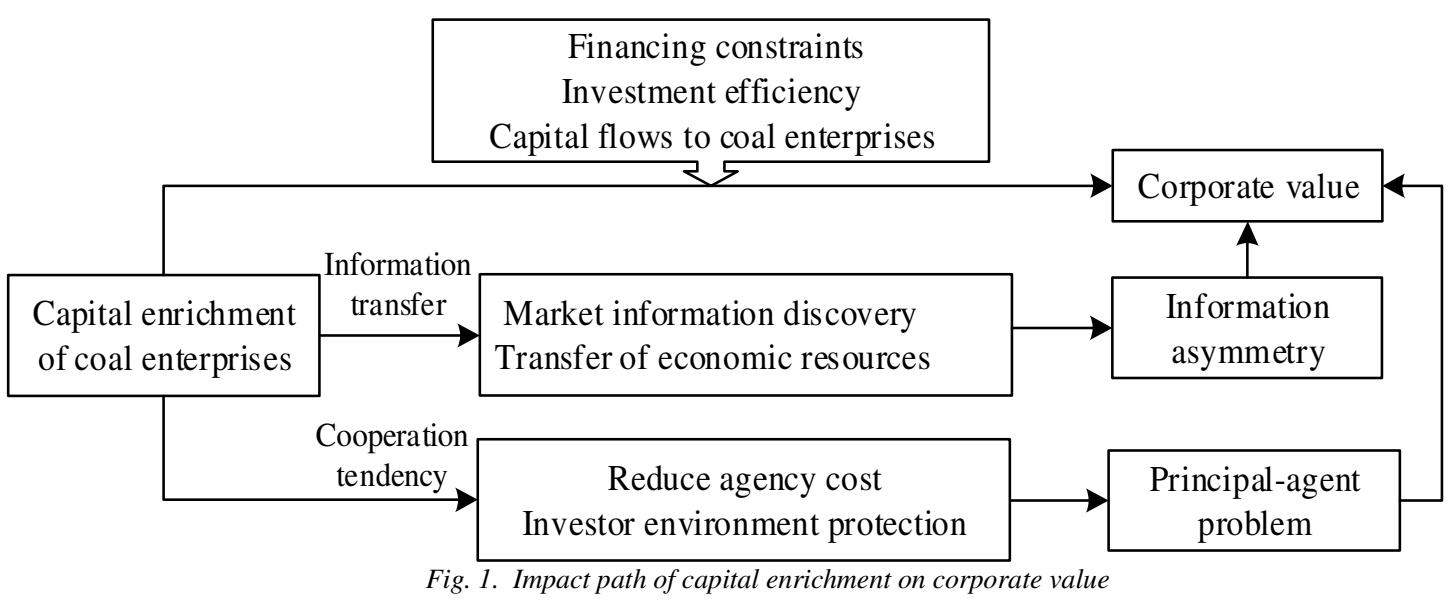

Methodology

\section{Research Subject and Data Sources}

Given the data availability limitations, this study considers coal enterprises in Shenzhen and Shanghai Stock Exchanges from the year 2011 to 2019 as research samples and conducts the following screening first: exclude the singularities, exclude samples with missing data, and exclude samples of ST and *ST during the research period. The missing values are calculated (included) through linear interpolation.

To eliminate the influence of extreme values, $1 \%$ and $99 \%$ Winsorization processing is carried out on all the data. All data are from CSMAR and WIND databases, and the software used for analysis is STATA 15.0.

\section{Variable Definition}

\section{Stakeholder Model of Social Responsibility of Coal Enterprises}

From the perspective of economics, it can be found that the capital flow reflects the cooperation tendency among transaction subjects. The long and high-yield investment projects promote information sharing between the coal companies and investors. It reduces agency costs and creates a better investor protection environment (Walaa, 2018), which plays an important role in improving coal enterprises' investment efficiency to achieve excess earnings and enhance their innovation capability (Lu et al., 2019). Therefore, the social responsibility of coal enterprises can affect corporate value indirectly through capital enrichment. The impact path is as shown in Figure 1, and the following hypothesis is proposed.

CSR's measurement has always remained an issue in the related studies (Mauricio, Lára and Brynhildur, 2019). The main available methods include the reputation index method, the content analysis method, and the KLD index method. The first two methods rely too much on experts' subjective judgment, which affects the objectivity of evaluation results. Cho, Lee, and Pfeiffer (2013) analyze the correlation between corporate social responsibility and information asymmetry using the KLD index method. It involves multiple companies in industries and can measure social responsibility across time dimensions. However, it relies on a large and comprehensive database, and there is a certain degree of subjectivity also in the variable selection.

Given a relatively immature social responsibility system and the incomplete data of coal enterprises, this study constructs the stakeholder model of coal enterprises' social responsibility from the perspective of capitalforms, including human capital, monetary capital, social capital, and environmental capital (Wen and Fang, 2008) as shown in Figure 2.

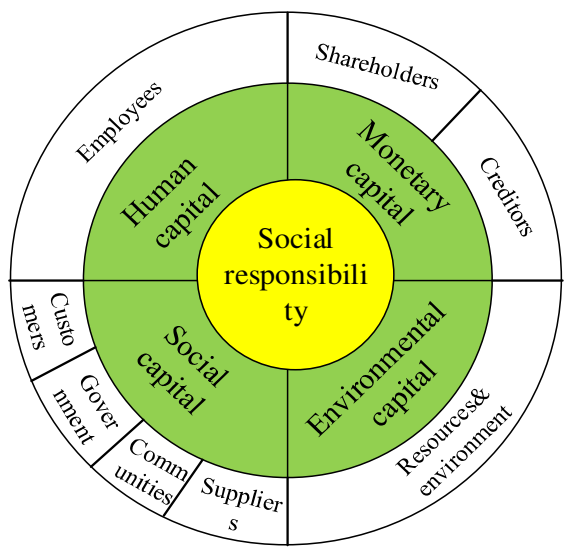

Fig. 2. Stakeholder model of coal enterprises' social responsibility 
Referring to Lindgreen, Swaen, and Johnston (2009); Pomarenko, Wolniak and Marinina (2016); Chae and Park (2018); and Tamvada (2020); the following 15 variables are selected to measure the social responsibility of coal enterprises, as shown in Table 1.

Tab. 1. Evaluation index system of social responsibility

\begin{tabular}{|c|c|c|c|}
\hline Dimension & Stakeholders & Variable and code & Measurement \\
\hline Human capital & Employees & Per capita annual income & Salary payable/number of employees \\
\hline \multirow{6}{*}{ Monetary capital } & \multirow{3}{*}{ Shareholders } & Basic earnings per share & $\begin{array}{l}\text { Net profit of ordinary shareholders /weighted } \\
\text { average of ordinary shares }\end{array}$ \\
\hline & & \multirow{2}{*}{$\begin{array}{c}\text { Return on Equity } \\
\text { Value preservation and appreciation rate } \\
\text { of capital }\end{array}$} & Profit after tax/owner's equity \\
\hline & & & Ending equity/beginning equity \\
\hline & & Asset-liability ratio & Total liabilities/total assets \\
\hline & Creditors & Quick ratio & Quick assets/current liabilities \\
\hline & & Interest coverage ratio & Profit before interest and tax/interest expense \\
\hline \multirow{5}{*}{ Social capital } & \multirow[t]{2}{*}{ Customers } & Increase rate of main business revenue & $\begin{array}{c}\text { Operating income this year/operating income last } \\
\text { year-1 }\end{array}$ \\
\hline & & $\begin{array}{l}\text { Operating Expense Ratio } \\
\text { Account payable turnover rate }\end{array}$ & $\begin{array}{l}\text { Operating cost/operating income } \\
\text { Operating cost/accounts payable }\end{array}$ \\
\hline & Suppliers & Cash to Accounts Payable ratio & $\begin{array}{l}\text { Net cash flow from operating activities/total } \\
\text { accounts payable }\end{array}$ \\
\hline & Government & $\begin{array}{l}\text { Income tax payment rate } \\
\text { Tax rate }\end{array}$ & $\begin{array}{c}\text { Income tax paid/average net assets } \\
\text { Total tax/total profit }\end{array}$ \\
\hline & Communities & Number of Employees & Total number of employees this year \\
\hline $\begin{array}{l}\text { Environmental } \\
\text { capital }\end{array}$ & $\begin{array}{l}\text { Resources \& } \\
\text { environment }\end{array}$ & Environmental protection expenditure & Total expenditure on environmental protection \\
\hline
\end{tabular}

Since the measurement units of different indexes are not the same, we use the entropy method to determine the normalized distribution function values. It is an objective valuation method that can analyze the weights of different indicators according to their varying degrees of importance. The greater the entropy, the higher the index's utility value, and the greater will be the weight.

First, assuming that there are $m$ evaluation indicators, $n$ the number of coal enterprises, the original matrix is $A=\left(\mathrm{a}_{i j}\right)_{m \times n}$, then $R=\left(r_{i j}\right)_{m \times n}$ is obtained after normalization, as shown in Equation (1).

$$
r_{i j}=\frac{a_{i j}-\min \left(a_{i j}\right)}{\max \left(a_{i j}\right)-\min \left(a_{i j}\right)}
$$

Second, the entropy value of the $i_{t h}$ index is determined according to Equation (2) and (3).

$$
\begin{gathered}
\mathrm{h}_{i}=-k \sum_{j=1}^{n} f_{i j} \ln f_{i j} \\
f_{i j}=r_{i j} / \sum_{j=1}^{n} r_{i j}
\end{gathered}
$$

Where $k=1 / \ln n$, and when $f_{i j}$ is $0, f_{i j} \ln f_{i j}$ is also 0 . Then the entropy weight of the $i$-th index is calculated according to Equation (4).

$$
\mathrm{w}_{i}=\frac{1-h_{i}}{m-\sum_{i=1}^{m} h_{i}}\left(0 \leq w_{i} \leq 1, \sum_{i=1}^{m} w_{i}=1\right)
$$

The result shows that the social responsibility to shareholders, resources and environment, and supplier stakeholders accounts for a relatively larger weight, with $0.2573,0.2479$, and 0.1445 , respectively. Coal enterprises have the lowest social responsibility for consumers, with a weight of 0.0225 .

\section{Other Core Variables}

(1) Corporate value

This study attempts to reveal the impact of social responsibility on the corporate value of Chinese coal enterprises. The applicability and accuracy of index selection affect the validity of the result directly. As can be seen from the existing research, the indicators such as return on assets, price-earnings ratio, price-to-book ratio, Tobin's Q, and economic value added are mainly used to measure corporate value. Tobin's Q considers both the 
book value and the market value, which can reflect the coal enterprise's true value. Therefore, it is selected to measure the corporate value here finally.

(2) Capital enrichment

Capital enrichment is the result of concentrated capital flows, which reflect the accumulation of capital across different regions and/or industries. The most intuitive manifestation of capital enrichment is the increase in the total capital amount based on different sources of capital (state capital, collective capital, corporate capital, individuals, Hong Kong, Macao, and Taiwan capital and foreign capital). This study defines the above total capital as the level of capital enrichment.

In the coal industry, total capital enrichment increased from 438.4 billion RMB in 2011 to 639.5 billion RMB in 2019, with a growth rate of $46 \%$. It reached the maximum in 2015, which was mainly due to the national policy support in that year. As a whole, the capital enrichment of the coal industry maintains a rising trend in fluctuations, as shown in Figure 3.

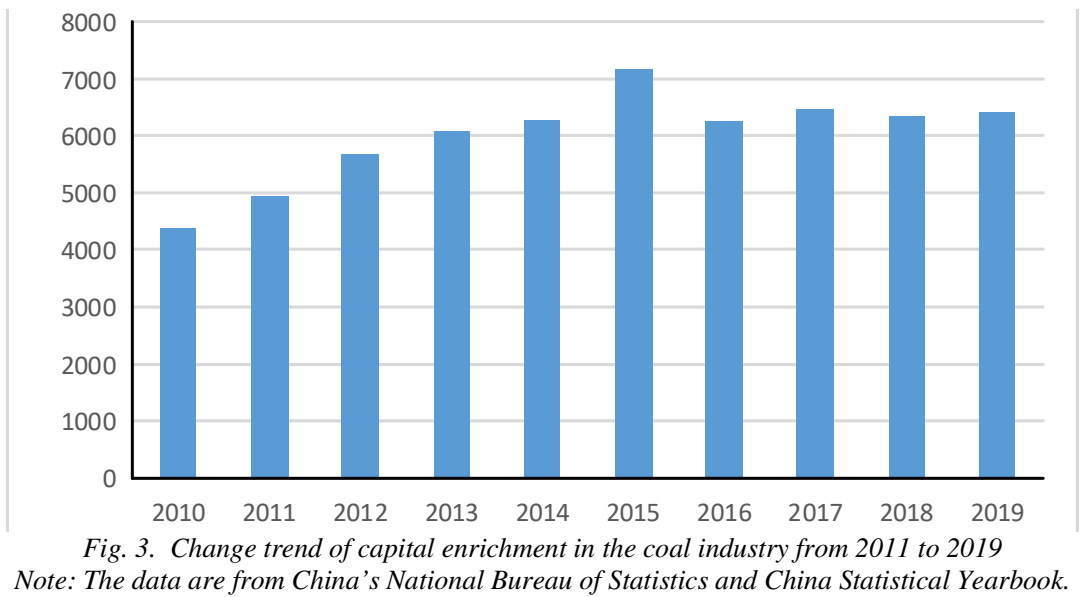

\section{Basic Model}

Most of the existing research on coal enterprises' corporate value is based on the static framework, ignoring the dynamic relationship between social responsibility and corporate value. Since the corporate value is a result of long-term value accumulation and is likely to be affected by the previous value, this study incorporates the lagged one period value into the model and employs the system GMM regression method for empirical testing. It is an estimation method based on the actual parameters satisfying certain moment conditions, allowing heteroscedasticity and serial correlation of random error terms. So the parameters can be estimated without knowing their accurate distribution information, and the results obtained are more effective than other traditional regression analysis methods such as the ordinary least squares method, the instrumental variable method, and the maximum likelihood method. Meanwhile, it effectively eliminates the possible threat of endogeneity. The basic GMM model constructed is shown in Equation (5).

$$
\text { Tobin's } Q_{i, t}=\alpha_{0}+\alpha_{1} \text { Tobin's } Q_{i, t-1}+\alpha_{2} \text { CSR }_{i, t}+\sum \text { Controls }_{i, t}+\varepsilon_{i, t}
$$

Where Tobin's $Q$ is the corporate value of coal enterprises, which is measured by market value/total assets, $C S R$ is the social responsibility of coal enterprises, measured by the comprehensive evaluation index obtained above, $t$ means the year, $\varepsilon$ is the random interference item, and Control $_{i, t}$ is representing the control variables.

Referring to Jo and Harhoto (2012); Flammer (2013); Wang and Li (2016); and Chae and Park (2018); the following control variables are selected: 1) Corporate size (Size), measured by the natural logarithm of total assets; 2) Debt asset ratio (Debt), measured by total debt/total assets at the end of the year; 3) Shareholding ratio of the largest shareholder (Top1), measured by the shares held by the largest shareholder/total shares; 4) Total profit (Profit), measured by the pre-tax profit; 5) Proportion of independent directors (Indep), measured by the number of independent directors/total number of board members; 6) Two positions in one (Duality), if the chairman and general manager are in the same position, assign a value of 1 , otherwise 0 .

In the first step, capital enrichment is initially included in the regression equation, as shown in Equation (6). Later, social responsibility is introduced to construct the new regression equation, as shown in Equation (7). Finally, to examine its channel effect, the interaction term of social responsibility and capital enrichment (CSR*Capital) is introduced to check whether social responsibility affects corporate value through capital enrichment, as shown in Equation (8). The centralization method is used to avoid multicollinearity issues, possibly caused by introducing the interaction term (Dalal and Zickar, 2012). 


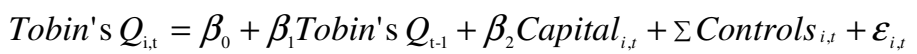

$$
\begin{aligned}
& \text { Tobin's } Q_{i, t}=\beta_{0}+\beta_{1} \text { Tobin's }_{Q_{1} 1}+\beta_{2} \operatorname{CSR}_{i, t}+\beta_{3} \text { Capital }_{i, t}+\Sigma \text { Controls }_{i, t}+\varepsilon_{i_{i, t}}
\end{aligned}
$$

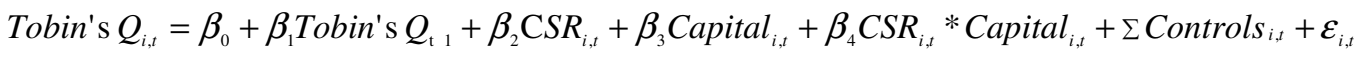

\section{Mediating Effect Model}

According to the theoretical analysis presented above, capital enrichment may mediate the relationship between social responsibility and corporate value. To test the mediating effect of capital enrichment, the model as shown in Equation (9), (10), and (11) is constructed by adopting the mediating effect test method proposed by Wen et al. (2004).

$$
\begin{aligned}
& \text { Tobin's } Q_{i, t}=\gamma_{0}+\gamma_{1} \text { Tobin's }_{Q_{i, t-1}}+\gamma_{2} \text { CRS }_{i, t}+\sum \text { Controls }_{i, t}+\varepsilon_{i, t} \\
& \text { Capital }_{i, t}=\gamma_{0}+\gamma_{1} \text { CRS }_{i, t}+\Sigma \text { Controls }_{i, t}+\varepsilon_{i, t} \\
& \text { Tobin's } Q_{i, t}=\gamma_{0}+\gamma_{1} \text { Tobin's } Q_{i, t-1}+\gamma_{2} C R S_{i, t}+\gamma_{3} \text { Capital }_{i, t}+\Sigma \text { Controls }{ }_{i, t}+\varepsilon_{i, t}
\end{aligned}
$$

To test the significance of this mediating effect, the Sobel statistic is used here. Sobel statistic's critical values can be judged through the critical values table, as shown in Equation (12).

$$
\text { Sobel }=\widehat{\gamma}_{1} \widehat{\mu}_{2} / \sqrt{\widehat{\gamma}_{1}^{2} S_{\mu_{2}}^{2}+\widehat{\mu}_{2}^{2} S_{n}^{2}}
$$

Where Sobel is the standard error of $\hat{\gamma}_{1} \hat{\mu}_{2}, \hat{\gamma}_{1}$ is the estimator of $\gamma_{1}, \hat{\mu}_{2}$ is the estimator of $\mu_{2}, S_{\gamma_{1}}$ and $S_{\mu_{2}}$ represent the standard error of $\gamma_{1}$ and $\hat{\mu}_{2}$, respectively.

\section{Results analysis}

\section{Scatter Plot Analysis}

The scatter plot method is used to intuitively investigate the raw relationship between the main variables, as shown in Figure 4.
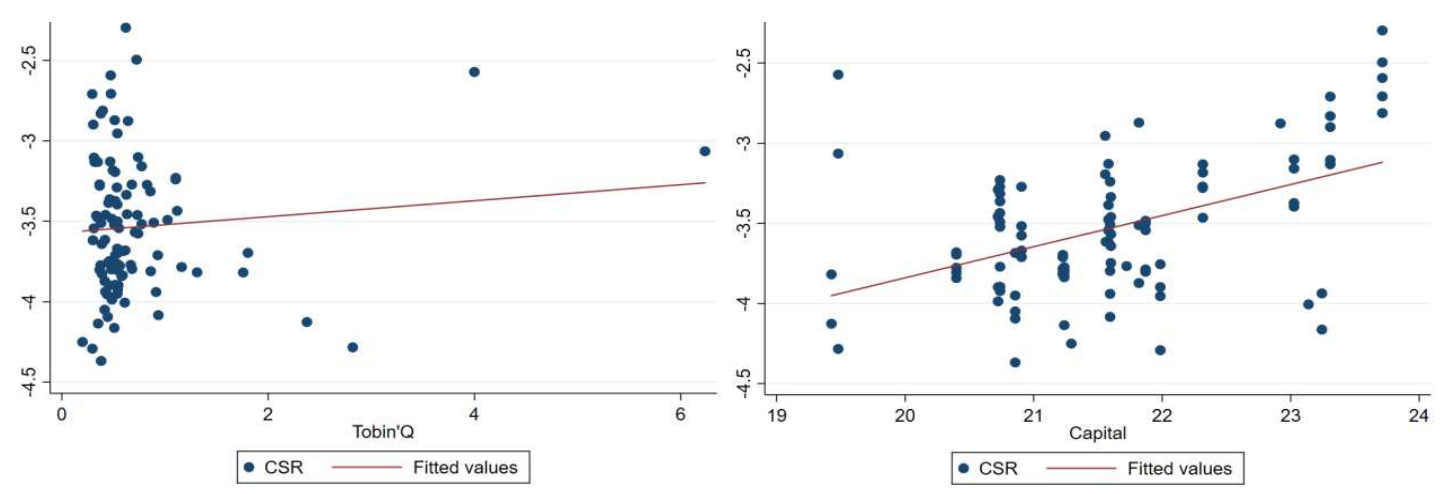

(a) Social responsibility and corporate value

(b) Social responsibility and capital enrichment

Fig. 4. Scatter plot between main variables

The scatter plots above show that the correlation between the main variables is consistent with the hypotheses proposed in this study. But this study suggests that coal enterprises' social responsibility affects corporate value directly and indirectly through capital enrichment. Therefore, this study further explores the transmission mechanism among social responsibility, corporate value, and capital enrichment by using China's coal enterprises' panel data.

\section{Transmission Mechanism}

This study introduces the lagged term of the explained variable, which may cause endogenous problems, so the GMM model is adopted to alleviate it. Compared with the system GMM, differential GMM may have the problem of weak instrumental variables, which influences the validity of the research results. So the system GMM is applied, and the Sargan statistic is used to test the validity of instrumental variables. Referring to Wintoki, Linck, and Netter (2012), the practice of determining the lag period of instrumental variables, the 
explained variable is lagged by one period to meet the homogeneity requirements.

First, the linear regression is performed on the social responsibility, corporate value, and capital enrichment of coal enterprises. Second, the interaction term of $C S R^{*}$ Capital is introduced, and possible collinearity problems are eliminated through centralized processing. The results are shown in Table 2.

Tab. 2. Basic regression results of variables

\begin{tabular}{|c|c|c|c|c|}
\hline Variable & Model(1) & Model(2) & Model(3) & Model(4) \\
\hline L.Tobin's Q & $0.557^{* * * *}(0.110)$ & $0.714^{* * * *}(0.098)$ & $0.313^{* * *}(0.125)$ & $0.422^{* * * *}(0.119)$ \\
\hline CSR & $0.580^{* * * *}(0.164)$ & & $0.763^{* * * *}(0.166)$ & $-2.930(1.848)$ \\
\hline Capital & & $0.456^{* *}(0.155)$ & $0.627^{* * *}(0.169)$ & $0.988^{* * * *}(0.333)$ \\
\hline CSR ${ }^{*}$ Capital & & & & $0.167^{* *}(0.087)$ \\
\hline Size & $-0.286^{* * * *}(0.056)$ & $-0.462^{* * * *}(0.140)$ & $-0.813^{* * * *}(0.153)$ & $-0.605^{* * * *}(0.132)$ \\
\hline Debt & $-0.386(0.246)$ & $-0.641^{* *}(0.258)$ & $-0.364(0.246)$ & $-0.719^{*}(0.401)$ \\
\hline Top1 & $-0.016^{* *}(0.006)$ & $-0.001(0.005)$ & $-0.013^{*}(0.007)$ & $-0.025^{* * *}(0.008)$ \\
\hline Profit & $0.644(0.779)$ & $0.115(0.085)$ & $0.103^{*}(0.081)$ & $0.018(0.091)$ \\
\hline Indep & $-0.337(0.872)$ & $-1.139(0.964)$ & $-1.638^{* *}(0.880)$ & $-0.821(0.936)$ \\
\hline Duality & $-0.294^{*}(0.186)$ & $-0.257^{*}(0.202)$ & $-0.701^{* * * *}(0.209)$ & $-0.460^{* * * *}(0.177)$ \\
\hline Constant & $9.440^{* * * *}(2.292)$ & $2.319(1.600)$ & $8.728^{* * *}(2.348)$ & $-1.860(6.077)$ \\
\hline Observations & 199 & 199 & 199 & 199 \\
\hline $\mathrm{AR}(1)$ & $-4.18^{* * *}$ & $-3.94^{* * *}$ & $-3.03^{* * *}$ & $-3.92^{* * *}$ \\
\hline $\operatorname{AR}(2)$ & 1.37 & 0.79 & 1.57 & 0.89 \\
\hline Sargan & 59.45 & 55.78 & 49.33 & 49.45 \\
\hline
\end{tabular}

Note: The data were generated by the authors. Robust standard errors in parentheses; $* p<0.1, * * p<0.05$, ***p $<0.01 ; N$ is the number of observations; $A R(1)$ and $A R(2)$ are the p-values of the first-order disturbance term and second-order disturbance term, respectively.

The result from Model (1) in Table 2 shows that coal enterprises' social responsibility has a direct positive impact on corporate value after controlling for other variables that may also affect corporate value. The coefficient is 0.580 , significant at $1 \%$, indicating that good performance in fulfilling social responsibility improves the corporate value. So the hypothesis $\mathrm{H} 1$ is verified. It implies that while pursuing economic interests, coal enterprises can satisfy the interest demands of different stakeholders if they take into account social and ecological interests. It creates a good market environment for the development of coal enterprises, which improves firm reputation and thus obtains more profitable opportunities. For example, the fulfillment of social responsibility towards employees can stimulate their enthusiasm and creativity and increase corporate productivity. The social responsibility fulfillment towards suppliers is beneficial to reduce the operating costs by maintaining long-term and stable cooperative relationships. The social responsibility towards the communities helps coal enterprises to establish good community relationships to obtain more government tax incentives and other resource advantages. These increase the free cash flows and the potential social capital stock, which will be further transformed into the actual productivity and market competitiveness of these coal companies for creating greater market value. Conversely, the coal enterprises with greater corporate value have more capital and the ability to undertake social responsibilities, thus forming a virtuous circle of social responsibility and corporate value.

The result in Model (2) shows that there is a positive association between capital enrichment and corporate value, which is significant at the 5\% level. It explains that the higher the capital enrichment level, the stronger the promoting effect on corporate value, which is consistent with previous research findings (Kum, Vinh, and Yiik, 2016; Mehralian et al., 2016). This study further emphasizes the transmission mechanism that social responsibility affects corporate value through capital enrichment. If it is right, in the regression model where corporate value is used as an explained variable, if the capital enrichment is removed, the effect of social responsibility on corporate value should remain significant. After introducing capital enrichment, as shown in Model (3), the coefficients of social responsibility and capital enrichment are 0.763 and 0.627 , respectively, and both of which are significant at $1 \%$. By further introducing the interaction term of CSR $*$ Capital, as shown in Model (4), social responsibility's regression coefficient becomes negative, and the interaction term is significantly positive. It shows that with an increase in social responsibility, capital enrichment's promotional effect on corporate value becomes enhanced.

\section{Heterogeneity Test}

To further analyze the impact of social responsibility towards different stakeholders on corporate value, the social responsibility in various dimensions is introduced, and the regression result is shown in Table 3.

It is evident from the results that the impact of social responsibility towards employees, shareholders, creditors, and resources and environment on corporate value is significantly positive at the $1 \%$ level, followed by the social responsibility for communities and suppliers, which is significant at $5 \%$ and $10 \%$, respectively. However, the regression coefficient of social responsibility towards government departments is negative. So, the impact of social responsibility on corporate value is heterogeneous towards different stakeholders, which is 
consistent with $\mathrm{H} 3$.

Tab. 3. Regression result of social responsibility of stakeholders in different dimensions and corporate value

\begin{tabular}{|c|c|c|c|c|c|c|}
\hline \multirow[t]{2}{*}{ Dimension } & \multicolumn{2}{|c|}{ Nonstandardized coefficient } & \multirow{2}{*}{$\begin{array}{l}\text { Standardized coefficient } \\
\quad \beta\end{array}$} & \multirow[b]{2}{*}{$\mathrm{t}$} & \multirow[b]{2}{*}{ Sig } & \multirow[b]{2}{*}{$\mathrm{R}^{2}$} \\
\hline & B & Std. error & & & & \\
\hline Employees & 98.988 & 33.623 & 0.261 & 2.944 & 0.004 & 0.460 \\
\hline Shareholders & 314.683 & 113.063 & 0.225 & 2.783 & 0.007 & 0.455 \\
\hline Creditors & 44.683 & 7.856 & 0.466 & 5.688 & 0.000 & 0.562 \\
\hline Customers & 76.474 & 957.483 & 0.007 & 0.080 & 0.937 & 0.410 \\
\hline Suppliers & 28.536 & 14.584 & 0.154 & 1.957 & 0.053 & 0.433 \\
\hline Government & -32.463 & 53.016 & -0.051 & -0.6122 & 0.542 & 0.412 \\
\hline Communities & 84.195 & 41.707 & 0.223 & 2.019 & 0.046 & 0.435 \\
\hline Resources \& environment & 30.577 & 6.435 & 0.494 & 4.752 & 0.000 & 0.525 \\
\hline
\end{tabular}

Note: The data were generated by the authors.

\section{Mediating Effect}

For further analysis and verification of $\mathrm{H} 2$, this study examines the mediating effect of capital enrichment on the relationship between social responsibility and corporate value, and the results are shown in Table 4.

Tab. 4. Mediating effect of capital enrichment

\begin{tabular}{|c|c|c|c|}
\hline Variable & $\begin{array}{l}\text { Model(1) } \\
\text { Tobin's Q }\end{array}$ & $\begin{array}{c}\text { Model(2) } \\
\text { Capital }\end{array}$ & $\begin{array}{l}\text { Model(3) } \\
\text { Tobin's Q }\end{array}$ \\
\hline L.Tobin's Q & $0.557^{* * *}(0.110)$ & & $0.277^{* *}(0.114)$ \\
\hline CSR & $0.580^{* * * *}(0.164)$ & $0.191^{* * * *}(0.061)$ & $0.764^{* * * *}(0.147)$ \\
\hline Capital & & & $0.550^{* * * *}(0.128)$ \\
\hline Size & $-0.286^{* * * *}(0.056)$ & $0.740(0.015)$ & $-0.796^{* * * *}(0.128)$ \\
\hline Debt & $-0.386(0.246)$ & $0.403^{* * * *}(0.110)$ & $-0.352^{*}(0.211)$ \\
\hline Top1 & $-0.016^{* * *}(0.006)$ & $-0.022^{* * *}(0.028)$ & $-0.016^{* * * *}(0.005)$ \\
\hline Profit & $0.064(0.078)$ & $-0.176^{* * *}(0.035)$ & $0.102(0.067)$ \\
\hline Indep & $0.337(0.872)$ & $2.141^{* * * *}(0.394)$ & $-1.143(0.765)$ \\
\hline Duality & $-0.294(0.186)$ & $0.254^{* * * *}(0.089)$ & $-0.396^{* *}(0.161)$ \\
\hline Constant & $9.440^{* * * *}(2.292)$ & $8.398^{* * * *}(0.650)$ & $10.185^{* * * *}(1.971)$ \\
\hline Observations & 199 & 199 & 199 \\
\hline $\operatorname{AR}(1)$ & $-4.18^{\text {***k }}$ & $-1.19^{* * *}$ & $-3.37^{* * *}$ \\
\hline $\operatorname{AR}(2)$ & 1.37 & 0.05 & 2.01 \\
\hline Sargan & 59.45 & 89.85 & 62.49 \\
\hline Sobel test & & 31 with the $\mathrm{P}$ valu & \\
\hline Proportion & & g Effect/Total Eff & \\
\hline
\end{tabular}

Note: The data were generated by the authors. Robust standard errors in parentheses; $* p<0.1, * * p<0.05$, ***p $<0.01 ; N$ is the number of observations; $A R(1)$ and $A R(2)$ are the p-values of the first-order disturbance term and second-order disturbance term, respectively.

The result in Model (1) shows that social responsibility's regression coefficient is 0.580 and significant at $1 \%$. This indicates that the total effect of social responsibility on corporate value is positive. In Model (2), the coefficient of social responsibility is still positive, demonstrating that coal enterprises' social responsibility has greatly enhanced the level of capital enrichment. In Model (3), the coefficients of social responsibility and capital enrichment are both positive and significant at $1 \%$. Therefore, the capital enrichment of coal enterprises indeed has a mediating effect on the relationship between social responsibility and corporate value which is consistent with $\mathrm{H} 2$. Additionally, the $\mathrm{Z}$ value of the Sobel test is 2.531 and significant at $1 \%$, indicating that capital enrichment's mediating effect is significant. It plays an important mediating role in the relationship between social responsibility and corporate value, which is manifested as the transmission mechanism of social responsibility $\rightarrow$ capital enrichment $\rightarrow$ corporate value. It once again proves the validity of $\mathrm{H} 2$.

\section{Robustness Test}

\section{Shifting Mean Values}

Considering that our variables' values fluctuate greatly every year, we process it three times and re-estimate the relationship between social responsibility, corporate value, and capital enrichment in coal enterprises. The results are shown in Model (1)-(3), Table 5.

As can be seen from Model (1), social responsibility has a significantly positive impact on corporate value, with a regression coefficient of 0.156 . After adding the mediating variable of capital enrichment, the results in Model (2) and (3) show that social responsibility is positively connected with capital enrichment and the coefficients of their influence on corporate value are 0.167 and 0.094 , respectively, both of which are significant. These results prove that social responsibility affects corporate value through capital enrichment. Additionally, the $\mathrm{Z}$ value in the Sobel test is 2.340 with the $\mathrm{P}$ value of 0.010 , indicating that capital enrichment's mediating effect is significant. 
Tab. 5. Robustness test results

\begin{tabular}{|c|c|c|c|c|c|c|}
\hline Variable & $\begin{array}{l}\text { Model(1) } \\
\text { Tobin's Q }\end{array}$ & $\begin{array}{c}\text { Model(2) } \\
\text { Capital }\end{array}$ & $\begin{array}{l}\text { Model(3) } \\
\text { Tobin's Q }\end{array}$ & $\begin{array}{l}\text { Model(4) } \\
\text { Tobin's Q }\end{array}$ & $\begin{array}{c}\text { Model(5) } \\
\text { Capital }\end{array}$ & $\begin{array}{l}\text { Model(6) } \\
\text { Tobin's Q }\end{array}$ \\
\hline L.Tobin's Q & $\begin{array}{l}1.120^{* * *} \\
(0.036)\end{array}$ & & $\begin{array}{l}1.110^{* * *} \\
(0.046)\end{array}$ & $\begin{array}{l}0.669^{* * * k} \\
(0.102)\end{array}$ & & $\begin{array}{c}0.547^{\text {*** }} \\
(0.106)\end{array}$ \\
\hline CSR & $\begin{array}{l}0.156^{* * * *} \\
(0.060)\end{array}$ & $\begin{array}{c}0.360^{* * *} \\
(0.037)\end{array}$ & $\begin{array}{l}0.167^{* * *} \\
(0.067)\end{array}$ & $\begin{array}{l}0.487^{* * *} \\
(0.144)\end{array}$ & $\begin{array}{l}0.213^{* * * *} \\
(0.067)\end{array}$ & $\begin{array}{l}0.536^{* * * *} \\
(0.138)\end{array}$ \\
\hline Capital & & & $\begin{array}{l}0.094^{\text {**** }} \\
(0.039)\end{array}$ & & & $\begin{array}{l}0.309^{\text {***k }} \\
(0.108)\end{array}$ \\
\hline Size & $\begin{array}{c}-0.041^{* * * k} \\
(0.018)\end{array}$ & $\begin{array}{c}0.760^{* * *} \\
(0.009)\end{array}$ & $\begin{array}{c}-0.056 \\
(0.046)\end{array}$ & $\begin{array}{c}-0.213^{\text {**** }} \\
(0.050)\end{array}$ & $\begin{array}{l}0.721^{\text {***k }} \\
(0.052)\end{array}$ & $\begin{array}{c}-0.482^{* * * *} \\
(0.105)\end{array}$ \\
\hline Debt & $\begin{array}{l}-0.143 \\
(0.139)\end{array}$ & $\begin{array}{l}0.253^{* * * *} \\
(0.081)\end{array}$ & $\begin{array}{c}-0.128 \\
(0.144)\end{array}$ & $\begin{array}{c}-0.397 \\
(0.253)\end{array}$ & $\begin{array}{l}-0.041 \\
(0.116)\end{array}$ & $\begin{array}{l}-0.394 \\
(0.241)\end{array}$ \\
\hline Top1 & $\begin{array}{l}-0.009^{* *} \\
(0.002)\end{array}$ & $\begin{array}{c}-0.015^{* * *} \\
(0.002)\end{array}$ & $\begin{array}{c}-0.009^{* * *} \\
(0.002)\end{array}$ & $\begin{array}{l}-0.014^{* * *} \\
(0.005)\end{array}$ & $\begin{array}{l}-0.006 \\
(0.007)\end{array}$ & $\begin{array}{c}-0.015^{* * * *} \\
(0.005)\end{array}$ \\
\hline Profit & $\begin{array}{c}0.068 \\
(0.025)\end{array}$ & $\begin{array}{c}-0.342^{* * *} \\
(0.022)\end{array}$ & $\begin{array}{c}0.009 \\
(0.025)\end{array}$ & $\begin{array}{c}0.054 \\
(0.065)\end{array}$ & $\begin{array}{l}-0.115^{* * *} \\
(0.045)\end{array}$ & $\begin{array}{c}0.104 \\
(0.064)\end{array}$ \\
\hline Indep & $\begin{array}{c}-0.096 \\
(0.088)\end{array}$ & $\begin{array}{l}0.777^{* * *} \\
(0.089)\end{array}$ & $\begin{array}{c}-0.116 \\
(0.103)\end{array}$ & $\begin{array}{c}-0.238 \\
(0.804)\end{array}$ & $\begin{array}{l}1.249^{* * * k} \\
(0.408)\end{array}$ & $\begin{array}{l}-0.893^{* * *} \\
(0.799)\end{array}$ \\
\hline Duality & $\begin{array}{c}0.083 \\
(0.509)\end{array}$ & $\begin{array}{l}5.589^{\text {***k }} \\
(0.543)\end{array}$ & $\begin{array}{c}-0.009 \\
(0.580)\end{array}$ & $\begin{array}{l}-0.328^{*} \\
(0.188)\end{array}$ & $\begin{array}{c}0.036 \\
(0.110)\end{array}$ & $\begin{array}{c}-0.426 \\
(0.182)\end{array}$ \\
\hline Constant & $\begin{array}{l}1.991^{* * * *} \\
(0.697)\end{array}$ & $\begin{array}{c}10.706^{* * * *} \\
(0.423)\end{array}$ & $\begin{array}{l}2.067^{* * * *} \\
(0.723)\end{array}$ & $\begin{array}{l}7.446^{* * * *} \\
(1.915)\end{array}$ & $\begin{array}{l}6.599^{* * * *} \\
(1.442)\end{array}$ & $\begin{array}{l}7.035^{* * * *} \\
(1.829)\end{array}$ \\
\hline Observations & $\begin{array}{l}199 \\
-176^{*}\end{array}$ & 199 & 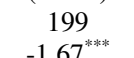 & 199 & 199 & 199 \\
\hline $\operatorname{AR}(2)$ & 0.65 & 0.29 & 0.65 & & & \\
\hline Sargan & 61.42 & 73.27 & 62.33 & & & \\
\hline $\mathrm{R}^{2}$ & \multirow{2}{*}{\multicolumn{3}{|c|}{$\begin{array}{c}\mathrm{Z}=2.340 \text { with the } \mathrm{P} \text { value of } 0.010 \\
\text { Mediating Effect/Total Effect }=21.69 \%\end{array}$}} & 0.319 & 0.457 & 0.377 \\
\hline $\begin{array}{l}\text { Sobel test } \\
\text { Proportion }\end{array}$ & & & & \multicolumn{3}{|c|}{$\begin{array}{c}\mathrm{Z}=2.127 \text { with the } \mathrm{P} \text { value of } 0.016 \\
\text { Mediating Effect/Total Effect }=13.50 \%\end{array}$} \\
\hline
\end{tabular}

\section{Fixed Effect Model}

The regression results of the fixed effects model are shown in Model (4)-(6), Table 4. The social responsibility in coal enterprises has a significant promoting effect on corporate value and capital enrichment, and the coefficients of control variables do not change significantly. Although the proportion of mediating effect in the total effect decreases from $18.86 \%$ to $13.50 \%$, all of them have passed the significance test. The transmission mechanism of social responsibility $\rightarrow$ capital enrichment $\rightarrow$ corporate value still exists, which once again verifies the mediating effect of capital enrichment to be true. Therefore, the research results obtained above can be called robust.

\section{Discussion}

Social responsibility has a positive effect on corporate value in coal enterprises, which demonstrates that being socially responsible is an essential requirement for these firms' sustainable development. However, the impact of social responsibility on corporate value is heterogeneous for different types of stakeholders.

According to the stakeholder theory and systematic corporate values, the fulfillment of social responsibility can better construct the cooperation mechanism between enterprises and stakeholders, improving the optimal allocation of social resources (Avishek and David, 2017). It is a channel to realize the comprehensive and potential value of the economy, society, and environment. For shareholders, they can obtain benefits through profit/dividend distribution, which is determined by the major shareholders. However, for employees, creditors, customers, suppliers, and resources and environment stakeholders, the benefits are mainly realized through explicit and/or implicit contractual relations ( $\mathrm{Yu}, 2016)$. In the multi-party contract, the stakeholders provide direct or indirect support for coal enterprises through the resource input, and enterprises focus on the sustainable enhancement of corporate values in return. The social responsibility activities increase corporate costs, such as expenditures for increasing employee welfare, improving the quality of coal products, and spending on technological innovation to reduce pollution emissions (Kasperowicz, 2015; Shindina et al., 2018; Rodrigo, Aqueveque and Duran, 2019). Although, the transaction and many other costs are reduced by establishing longterm and stable cooperative relationships with stakeholders (Lindgreen, Swaen and Johnston, 2009). Meanwhile, social responsibility investment can be transformed into the corporate social reputation, consumer trust, and sales profit (Debnath, Tandon and Lee, 2018; Vuković et al., 2020) to achieve high-value growth.

Table 4 shows that capital enrichment plays a role of mediating effect between social responsibility and corporate value, which indicates the influencing mechanism of social responsibility $\rightarrow$ capital enrichment $\rightarrow$ enterprise value.

The most intuitive manifestation of capital enrichment lies in the significant increase in the total capital 
amount. Since, social responsibility is like a signal transmission channel for coal enterprises which improves social trust and reputation (Park, Lee and Kim, 2014; Hegner, Beldad and Kraesgenberg, 2016), reduces financing constraints (He, Xiao and Chen; 2012; Cheng, Ioannou and Serafeim, 2014), and alleviates information asymmetry (Luo et al., 2015; Wang and Li, 2016). It promotes more capital inflows to the coal enterprises forming the capital foundation for innovative development. Coal enterprises with a higher level of capital enrichment have the more effective function of identifying investment opportunities, promoting optimal resource allocation, and accelerating the flow and agglomeration of personnel, information, technology, and other factors. In this way, such enterprises become more inclined to implement green coal technology innovation, such as the technical renovation of existing production lines, improvement of coal mining mechanization and production facilities, etc. To develop clean energy and deepen the supply-side structural reforms in the coal industry with the goal of building new energy enterprises is the essential requirement of corporate value growth recently.

\section{Conclusions}

The development of China's coal enterprises has attracted extensive attention from the world, and its social responsibility towards different stakeholders has also become a hot issue in academic research recently. This study uses China's coal enterprises' panel data from 2011 to 2019 and analyses the impact of social responsibility on corporate value based on the stakeholder theory. The main findings are as follows.

First, the stakeholder model of coal enterprises' social responsibility is constructed from dimensions of human capital, monetary capital, social capital, and environmental capital. The entropy weight method and the GMM model are used for empirical research, and the results show that good performance on social responsibility of coal enterprises can significantly improve their corporate value.

Second, the impact of social responsibility on corporate value is heterogeneous for stakeholders in different dimensions. The social responsibility for employees and shareholders has the greatest contribution to corporate value and is followed by creditors' social responsibility, resources, and environment. However, the social responsibility for customers and government departments is not related to a corporate value, according to our findings.

Third, capital enrichment of coal enterprises plays an important mediating role in the relationship between social responsibility and corporate value, and the transmission mechanism is manifested as social responsibility $\rightarrow$ capital enrichment $\rightarrow$ corporate value.

The implications of this study are as follows. First, improve the social responsibility database of coal enterprises. Most enterprises use financial indicators to measure social responsibility performance, rarely involving non-financial indicators, resulting in insufficient effectiveness of social responsibility information disclosure. The comprehensive social responsibility database helps to evaluate the performance of the social responsibility of coal enterprises more systematically and accurately. Second, create a good institutional environment for social responsibility. In recent years, coal enterprises have realized the importance of fulfilling their social responsibilities. However, there is no standardized and unified social responsibility disclosure standard, and the level of social responsibility undertaken by different coal enterprises varies greatly. Therefore, measures should be taken to explore and formulate the evaluation criteria, and thus improving the information disclosure quality. The governments should encourage coal enterprises to perform their social responsibilities actively. Third, give a full play to the promotion effect of capital enrichment, and strengthen coal enterprises' supervision to undertake social responsibilities, including the internal self-supervision, external industry supervision, and public opinion supervision. This is of great significance to the sustainable development of this country's national strategic energy resource like coal.

The topic for further directions. This study analyses the relationship between social responsibility, corporate value, and capital enrichment in China's coal enterprises using the system GMM model. However, given that capital enrichment results from long-term capital inflows in the coal industry, the sample period for empirical testing is relatively short. The mediating role of capital enrichment in social responsibility and corporate value needs to be tested for a longer period of time. Additionally, the capital enrichment levels in low-tech and hightech coal enterprises may also be different, but this study does not consider the heterogeneity of capital enrichment caused by such differences. In future research, the sample period will be expanded to at least 20 years to re-perform the empirical tests. The group testing mechanisms will also be adopted to check for the localized differences in the mediating effect of capital enrichment and further improve the research results' accuracy. 


\section{References}

Pomarenko, T.V., Wolniak, R., and Marinina, O.A. (2016). Corporate Social responsibility in coal industry (Practices of Russian and European companies). Journal of Mining Institute, 222, 882-891.

Avishek, B. and David, J. (2017). Corporate social responsibility and capital allocation efficiency. Journal of Corporate Finance, 43(1), 354-377.

Baron, D.P. (2001). Private politics, corporate social responsibility and integrated strategy. Journal of Economics and Management Strategy, 10(1), 7-45.

Borghesi, R., Houston, J.F. and Naranjo, A. (2012). Corporate socially responsible investments: CEO altruism, reputation and shareholder interests. Journal of Corporate Finance, 26(7), 164-181.

Carroll, A.B. (1979). A three-dimensional conceptual model of corporate performance. Academy of Management Review, 4(4), 497-505.

Chae, B. and Park, E. (2018). Corporate social responsibility: a survey of topics and trends using twitter data and topic modeling. Sustainability, 10(7), 2231.

Cheng, B., Ioannou, I. and Serafeim, G. (2014). Corporate social responsibility and access to finance. Strategic Management Journal, 35(1), 1-23.

Cheng, Q., Goh, B.W. and Kim, J.B. (2018). Internal control and operational efficiency. Contemporary Accounting Research, 35(2), 1102-1139.

Cho, S.Y, Lee, C. and Pfeiffer, R.J. (2013). Corporate social responsibility performance information and information asymmetry. Journal of Account Public Policy, 32(1), 71-83.

Connelly, B.L., Certo, S.T., Ireland, R.D. and Reutzel, C.R. (2011). Signaling theory: a review and assessment. Journal of Management, 37(1), 39-67.

Crisóstomo, V.L., Freire, F.D.S. and Vasconcellos, F.C.D. (2011). Corporate social responsibility, firm value and financial performance in Brazil. Social Responsibility Journal, 7(2), 295-309.

Dalal, D.K. and Zickar, M.J. (2012). Some common myths about centering predictor variables in moderated multiple regression and polynomial regression. Organizational Research Methods, 15(3), 339-362.

Debnath, S.C., Tandon, S. R. and Lee, B. B. (2018). Profit maximization versus stakeholders view of corporate social responsibility: an experiential exercise on ethics and social responsibility for business school courses. International Journal of Business Administration, 9(6), 69-75.

Dhaliwal, D.S., Li, O.Z., Tang, A.Y. and George, Y. (2011). Voluntary non-financial disclosure and the cost of equity capital: the initiation of corporate social responsibility reporting. Accounting Review, 86(1), 59100.

Dustin, S., Eric, R. (2020). CSR commitments, perceptions of hypocrisy, and recovery. International Journal of Corporate Social Responsibility, 5, 1.

Fernández-Guadaño, J. and Sarria-Pedroza, J. (2018). Impact of corporate social responsibility on value creation from a stakeholder perspective. Sustainability, 10(6), 2062.

Flammer, C. (2013). Corporate social responsibility and shareholder reaction: the environmental awareness of investors. Academy of Management Journal, 56(3), 758-781.

Godfrey, P.C., Merrill, C.B. and Hansen, J.M. (2009). The relationship between corporate social responsibility and shareholder value: an empirical test of the risk management hypothesis. Strategic Management Journal, 30(4), 425-445.

$\mathrm{Gu}, \mathrm{X}$. and Xu, W.W. (2011). Research on the correlation between social responsibility and corporate value based on stakeholders. Communication of Finance and Accounting, 3(1), 125-127.

Guo, W., Wang, Q.S. and Chen N. (2011). Research on the status and countermeasures of the social responsibility information disclosure of coal enterprises in China. Accounting Research, 12, 70-72.

He, X.J., Xiao, T.S. and Chen, X.Y. (2012). Corporate social responsibility disclosure and financing constraints. Journal of Finance and Economics, 38(8), 60-71.

Hegner, S.M., Beldad, A.D. and Kraesgenberg, A.L. (2016). The impact of crisis response strategy, crisis type and corporate social responsibility on post-crisis consumer trust and purchase intention. Corporate Reputation Review, 19(4), 357-370.

Herbas, T.B., Frank, B., Arandia, T.C. (2018). Corporate social responsibility in Bolivia: meanings and consequences. International Journal of Corporate Social Responsibility, 3, 7.

Isabel, M. and García, S. (2020). The moderating role of board monitoring power in the relationship between environmental conditions and corporate social responsibility. Business Ethics: A European Review, 29(2), $122-142$.

Wurgler, J. (2000). Financial markets and the allocation of capital. Journal of financial economics, 58(1-2), 187214.

Jo, H. and Harhoto, M.A. (2012). The causal effect of corporate governance on corporate social responsibility. Journal of Business Ethics, 106(1), 53-72. 
Kasperowicz, R. (2014). Economic growth and energy consumption in 12 European countries: a panel data approach. Journal of International Studies, 7(3), 112-122.

Kasperowicz, R. (2015). Economic growth and CO2 emissions: the ECM analysis. Journal of International Studies, 3(3), 91-98.

Kim, H.R., Lee, M., Lee, H.T. and Kim N.M. (2010). Corporate social responsibility and employee company identification. Journal of Business Ethics, 95(4), 557-569.

Kondić, V. and Balić, I. (2019). Leadership and conflict management in production organisations. Tehnički Glasnik 2019, 13(4), 356-362.

Kum, F.Y., Vinh, V.T. and Yiik, D.W. (2016). The Effect of continuous improvement capacity on the relationship between of corporate social performance and business performance in maritime transport in singapore. Transportation Research Part E: Logistics and Transportation Review, 95(1), 62-75.

Li, F., Li, T. and Minor, D. (2015). CEO power, corporate social responsibility and firm value: a test of agency theory. International Journal of Managerial Finance, 12(5), 611-628.

Lin, Y.R. and Fu, X.M. (2017). Does institutional ownership influence firm performance? Evidence from China. International Review of Economics and Finance, 49, 17-57.

Lindgreen, A., Swaen, V. and Johnston, W.J. (2009). Corporate social responsibility: an empirical investigation of US organizations. Journal of Business Ethics, 85(S2), 303-323.

Liu, J.H. (1999). Corporate social responsibility. Law Press, Beijing, China.

Liu, J.Q. and Song, X.Z. (2011). Differences in the Effect of Corporate Social Responsibility Dimensions on Corporate Value. Journal of Guizhou University of Finance and Economics, 5, 65-71.

Long, W.B. and Song, X.Z. (2013). Research on the path and time of social responsibility investment to increase value creation: a theoretical analysis. Accounting Research, 12, 60-64.

Lorenzo, A., Javier, C.H., Pablo, D.R., Pierpaolo, P. (2018). Corporate social responsibility and environmental management invites contributions for a special issue on sustainable innovation: Processes, strategies, and outcomes. Corporate Social Responsibility and Environmental Management, 25(1), 106-109.

Lu, J.T., Ren, L.C., He, Y.F., Lin, W.F. and Streimikis, J. (2019). Linking corporate social responsibility with reputation and brand of the firm. Amfiteatru Economic, 21(51), 442-460.

Lu, J.T., Ren, L.C., Yao, S.Q., Rong D., Skare, M. and Streimikis, J. (2020). Renewable energy barriers and coping strategies: evidence from the Baltic States. Sustainable Development, 28(1), 352-367.

Luo, X., Wanf, H., Raithel, S. and Zheng, Q.Q. (2015). Corporate social performance, analyst stock recommendations and firm future returns. Strategic Management Journal, 36(1), 123-136.

Lyon, T.P. and Maxwell, J.W. (2008). Corporate social responsibility and the environment: a theoretical perspective. Review of Environmental Economics and Policy, 2(2), 240-260.

Ma. L.N., Xu, F.J., Najaf, I. and Taslima, A. (2020). How does increased private ownership affect financial leverage, asset quality and profitability of Chinese SOEs?. Chinese Political Science Review, https://doi.org/10.1007/s41111-020-00158-x.

Mauricio, A.L.A., Lára, J., Brynhildur, D. (2019). A literature review of the history and evolution of corporate social responsibility. International Journal of Corporate Social Responsibility, 4, 1.

Mehralian, G., Nazari, J.A., Zarei, L. and Rasekh, H.R. (2016). The effects of corporate social responsibility on organizational performance in the Iranian pharmaceutical industry: the mediating role of TQM. Journal of Cleaner Production, 135, 689-698.

Orlando, G. (2020). Optimal growth under socially responsible investment: a dynamic theoretical model of the trade-off between financial gains and emotional rewards. International Journal of Corporate Social Responsibility, $5,5$.

Park, J., Lee, H. and Kim, C. (2014). Corporate social responsibilities, consumer trust and corporate reputation: South Korean consumers perspectives. Journal of Business Research, 67(3), 295-302.

Quan, X.F., Wu, S.N. and Yin, H.Y. (2015). Corporate social responsibility and stock price crash risk: value tool or self-serving tool? Economic Research Journal, 50(11), 49-64.

Rita, D.M. and Diego, R.M. (2020). Corporate social responsibility for poverty alleviation: an integrated research framework. Business Ethics: A European Review, 29(1), 122-148.

Rjiba, H., Jahmane, A. and Abid, I. (2020). Corporate social responsibility and firm value: guiding through economic policy uncertainty. Finance Research Letters, 35, 101553.

Rodrigo, P., Aqueveque, C. and Duran, I.J. (2019). Do employees value strategic CSR? A tale of affective organizational commitment and its underlying mechanisms. Business Ethics: A European Review, 28(4), 459-475.

Rothenhoefer, L.M. (2019). The impact of CSR on corporate reputation perceptions of the public-A configurational multi-time, multi-source perspective. Business Ethics: A European Review, 28(2), 141155. 
Ruf, B.M., Muralidhar, K., Robea, M.B., Jay, J.J. and Karen, P. (2001). An empirical investigation of the relationship between change in corporate social performance and financial performance: a stakeholder theory perspective. Journal of Business Ethics, 32(2), 143-156.

Sadok, E.G., Ghoul, O.G. and Yongtae K. (2017). Country-level institutions, firm value and the role of corporate social responsibility initiatives. Journal of International Business Studies, 48(3), 360-385.

Sekhon, A.K. and Kathuria, L.M. (2019). Analyzing the impact of corporate social responsibility on corporate financial performance: evidence from top Indian firms. Corporate Governance: The International Journal of Business in Society, 20(1), 143-157.

Shen, N. and Liu, F.C. (2012). Can high-strength environmental regulations really promote technological innovation? Retest based on Porter hypothesis. China Soft Science, 4, 49-59.

Shindina, T., Streimikis, J., Sukhareva, Y. and Nawrot, Ł. (2018). Social and economic properties of the energy markets. Economics and Sociology, 11(2), 334-344.

Tamvada, M. (2020). Corporate social responsibility and accountability: a new theoretical foundation for regulating CSR. International Journal of Corporate Social Responsibility, $5,2$.

Vollrath, D. (2009). How important are dual economy effects for aggregate productivity. Journal of Development Economics, 88(2), 325-334.

Vuković, A., Miletić, L., Čurčić, R., Ničić, M. (2020). Consumers’ perception of CSR motives in a post-socialist society: the case of Serbia. Business Ethics: A European Review, 29(3), 528-543.

Waddock, S.A. and Graves, S.B. (2015). The corporate social performance-financial performance link. Strategic Management Journal, 18(4), 303-319.

Walaa, .W.E. (2018). Corporate governance risk and the agency problem. Corporate Governance: The International Journal of Business in Society, 18(2), 254-269.

Wang, K.T. and Li, D. (2016). Market reactions to the first-time disclosure of corporate social responsibility reports: evidence from China. Journal of Business Ethics, 138(4), 661-682.

Wen, S.B. and Fang, Y. (2008). An empirical research on relationship between corporate social responsibility and financial performance: analysis based on stakeholder theory and panel dates. China Industrial Economics, 10, 150-160.

Wen, Z.L., Zhang, L., Hou, J.Q. and Liu, H.Y. (2004). Testing and application of the mediating effects. Acta Psychologica Sinica, 36(5), 614-620.

Wintoki, M.B., Linck, J.S. and Netter, J.M. (2012). Endogeneity and the dynamics of internal corporate governance. Journal of Financial Economics, 105(3), 581-606.

Woo, K., Kunsu, P. and Sang, L. (2018). Corporate social responsibility, ownership structure and firm value: evidence from Korea. Sustainability, 10(7), 2497-2516.

Xu, F.J., Ma. L.N., Li, X.Y. and Najaf, I. (2020). Capital enrichment, innovation capability and environmental pollution effect: evidence from China's manufacturing industry. Nature Environment and Pollution Technology, 19(3), 1141-1148.

Xu, F.J., Ma. L.N. and Najaf I. (2020). Interaction mechanism between sustainable innovation capability and capital stock: based on PVAR model. Journal of Intelligent and Fuzzy Systems, 38(6), 7009-7025.

Yu, H.Y., Huang, X.Z. and Cao, X. (2015). The relationship between corporate social responsibility and corporate performance, the moderating role of enterprises' social capital. Management Review, 27(1), 169-180.

Yu, F. (2016). The impact of corporate social responsibility upon corporate financial performance and its transmission mechanism. Shenzhen University Journal (Humanities Social Sciences), 33(2), 82-87.

Zerbini, F. (2017). CSR initiatives as market signals: a review and research agenda. Journal of Business Ethics, 146(1), 1-23. 